\title{
TRANSLATION OF POETRY BY ISTVÁN KEMÉNY
}

\author{
Gábor Mezei \\ Eötvös Loránd University \\ gmezeig@gmail.com \\ István Kemény \\ kemenyistvan01@gmail.com
}

\begin{abstract}
About the Translator
Gábor Mezei is a poet and Assistant Lecturer at the Department of Comparative Literature and Cultural Studies, Eötvös Loránd University, Budapest. His main fields of interest are 2othcentury Hungarian literature, media theory and the concepts of writing. He is the author of several articles on these topics, and his first monograph was published in 2016. He has published two volumes of poetry: függelék. [appendix.] in 2012 and natúr öntvény [raw alloy] in 2016. His poems have been translated into German and Czech.
\end{abstract}




\section{INTRODUCTION}

István Kemény is one of the most important living Hungarian poets at the turn of the $21^{\text {st }}$ century: "We all come out from Kemény's overcoat," I once said, obviously with some infatuation, and I do not think differently today, I would just put it more carefully: we can hardly pull ourselves from his sphere of influence.

According to Lajos Parti Nagy, "[Kemény] is a fundamental person, he cannot really be avoided, though I could not say that he would stand in anyone's way." Besides his own generation, the ones who have started their career at the beginning of the 1980s (Árpád Kun, Krisztina Tóth, István Vörös), he has affected at least two but rather three generations of poets (starting with János Térey and Krisztián Peer, through Zoltán Sopotnik and Péter Pollágh, till Márió Nemes Z. and Renátó Fehér) who were influenced by his work, every period of which is revealing as Kemény conquers newer and newer degrees of freedom, and he compels his readers towards hem. In the beginning of his career, countering the "ideal of the poem" that was expected from socialist cultural politics, he built different myths, legends or even elements of science fictions into the world of his poems, consciously and with a playful attitude, then later he mixed them together slowly into an own mythology, and he got more and more airily capable of forming seemingly banal sentences into poems - amongst other things, that is why he has been called "the" postmodern poet from the middle of the 1990 .

Apparently, this category was narrow for him, as well: as he is able to and dares to "worsen" poems intentionally, or as he has revitalized public poetry that was considered to be avoided in the 15 years following the system change (with his poems Búcsúlevél and Nyakkendö): all of these gestures are about the primal demand for freedom and fully experiencing it.

Translating the poems by István Kemény does not seem to be especially problematic at first glance, as the language used here is as if it was spoken. On the level of words, this poetry is plane, simple, almost minimalist. But these calm, even sentences, lacking all sudden changes within the texture are taking little curves, and this way they are more and more directing the flow of speech. The vocabulary is minimalist, but it operates with synonyms built into iterative structures, taking the reader out of the context, while creating new links within the text. The most difficult task to be done here for the translator is to keep up with these processes, these displacements of the text, the basis of which are simple words, that at the same time must create new semantic links as well. These links make it possible for Away to get really close to nonsensical utterances, as a really refined web of meanings are keeping them in context.

Kritika Kultura 28 (2017): -329

(c) Ateneo de Manila University

$<$ http://journals.ateneo.edu/ojs/kk/> 
Another aspect I have to deal with is the rhythm of the texts. Visiting the King may be a relevant example here, because the rhythm of prose was something I had to pay close attention to. This whole text contains one sentence, so it is especially important to keep up with the pace, to have almost as long subordinate clauses as the Hungarian version. But it was sometimes complicated, as the Hungarian language uses much more syllables than the English, though it is not too favorable to have shorter sentences in the translation. It could not be a solution to add new words either, as the economy of the text had to be kept in mind. And this rhythm was sometimes variated with rhymes embedded within lines, producing a kind of arrhythmia. The question of rhyme and rhythm was not such an important factor in 2oth Century, Version " $B$ ", as the metrical form determines many decisions through the process of translation.

As far as the cultural differences are concerned, the translation text did not have to bridge too big gaps. And not only because for example the poem Away contains quite evident references, like Karl May, but it uses these without their contexts, just like it does with the geographical reference, Danube. It does not work as a symbol here, it is a meaningless setting for the scene. These texts are using the most general statements possible, what makes them highly interesting is how they transform them, but it does not happen through evoking cultural contexts. The idiom "all the roads lead to Rome" is - the paraphrase of which is the starting point of 2oth Century, Version " $B$ " - is on the one hand quite widely known, almost a cliché, but it is understood literally, and that is how the aforementioned displacement starts in this case. So it is more like the semantic tension created by a minimalist vocabulary and a highly effective rhythm that makes this poetry unexpectedly enigmatic. What is lyrical here is surprisingly out of nowhere. This unlocatable nature makes it accessible through translation, though the enigma itself is highly needed for the Kemény-experience; the English version hopefully contains it. 


\section{ISTVÁN KEMÉNY'S PUBLISHED WORKS:}

Csigalépcsö az elfelejtett tanszékekhez (poems, 1984)

Játék méreggel és ellenméreggel (poems,1987)

Az ellenség müvészete (novel, 1989, 2011)

Témák a Rokokó-filmböl (poems, 1991)

A koboldkórus (poems, 1993)

A Kafka-paradigma (essays, with István Vörös, 1994)

A néma $H$ (poems, 1996)

Család, gyerekek, autó (short stories, 1997, 2011)

Valami a vérröl (selected and new poems, 1998)

Hideg (poems, 2001)

Élőbeszéd (poems, 2006)

Kedves Ismeretlen (novel, 2009)

Állástalan táncosnő (collected poems 1980-2006, 2011)

A királynál (poems, 2012) 


\section{VISITING THE KING}

I know you are preparing for battle, Sir, and your time is precious, for maybe it will be your last night, your captains are waiting, because even your strategy is incomplete, and your servants are making your luxurious, though light and perhaps last feast, and girls in their colorful tents are beautifying themselves in a hurry, you do not have much time left to chatter, especially because I've come from the enemy camp, I've grown up and learned there, there I was in love, and there is my past, though I am not a traitor, but a traveller, a wanderer, wise and impudent, very brave at the moment and even a bit surprised at that, but neither mad nor drunk, and I do not want to kill or to divert you, I've simply come to ask, whether you send a message towards the very edge, since I am just on my way, to call or shout from over there, as I'm bored with God keeping silent. 


\section{AWAY}

There go the water trucks with pure reason instead of water. The fortune-tellers come behind them quarrelling, as usual. The clouds above them with their keyboards, unreachable. All, away, in the same direction. In that direction reels are unwound. That way dogs saunter off with tails between legs. And the musicians wear tails, even the court musicians. Those are the jesters, dragging their form across the ground. And that is the way the Danube is flowing, carrying, comforting its water. All, away, in the same direction.

"Look, Papa! There go the girls, all so beautiful!"

"I see... what have you smeared your vest with?"

There goes Shining Instinct stealthily, from memory to memory. There goes Karl May driving smallpox away.

There are teachers promenading teachers, orderly, leggy.

There goes the cycling tour that was missed.

There rolls the ball at the end of a biro in distant notebooks.

There goes the car from Lisbon, a cloud of cigar-smoke around, and there is Móni getting off, who later did not want to live.

All, away, in the same direction.

"Look, Mama! There go the men, all so handsome!"

"I see... but what happened to your vest, my little stain?"

There fly the wild geese and their cries.

The black one behind is the force that brings and takes them away.

This way the surface dries up, and the channel drains down.

There is spring, summer, autumn, winter in separate plastic bags.

There go the ones who were seen once, and who were many times, and who weren't at last.

There go the old ones and those to come.

There go the old ones and those to come.

There go the water trucks with pure reason instead of water.

All, away, in the same direction. 


\section{TH CENTURY, VERSION B}

To death are we led by all the roads.

I'm shocked, I'm just waiting,

Dark green area around Rome:

This is the Town that's easy to miss.

To death are we led by all the roads,

All the roads crowded with caravans.

Pine-forests, justified dismay:

This is not the edge of Rome for sure.

Inhabited pit under the highway,

Most cars are misty and soiled,

A whole century has interfered,

This is not the edge of Rome for sure.

The petrol, if it's hiding or flowed,

Cannot be refilled any more,

What works here is what was one's own -

An endlessly invisible grey tour.

Crazy little guys stoning the convoy

And this century is starting once more.

Just that conditions are presently worse,

I'm shocked, I'm just waiting:

To death are we led by all the roads,

This is the Town that's easy to miss.

Green rage-area around Rome -

The Town is until two oceans headed. 


\section{KEMÉNY ISTVÁN}

\section{A KIRÁLYNÁL}

Tudom, hogy csatára készülsz, uram, és az időd drága, lehet, hogy ez lesz az utolsó estéd, vezéreid várnak, mert stratégiád se tökéletes még, és szakácsaid már készítik pompás, de könnyü, talán utolsó lakomádat, színes sátrakban pedig sietve szépítkeznek a lányok, nincs most időd sokat fecsegni, pláne, hogy bár az ellenség táborából jöttem, ott nőttem fel, ott tanultam, ott voltam szerelmes és ott a múltam, nem áruló vagyok mégsem, hanem utazó, vándor, bölcs és szemtelen, most nagyon bátor és egy kissé meglepett is ettől, de se nem őrült, se nem részeg, és se megölni, se eltéríteni nem akarlak téged, egyszerűen csak jöttem megkérdezni tőled, hogy üzensz-e valamit a Legszélére, mert én oda tartok éppen, hogy átszóljak vagy átkiabáljak onnan, mert meguntam, hogy hallgat az Isten. 
EL

Ott mennek a locsolóautók víz helyett tiszta ésszel.

Mögöttük a jósnők, most is veszekedve.

Fölöttük a felhők, elérhetetlen billentyűzetükkel.

Mind, el, ugyanarra. Ugyanarra tekerednek le az orsók.

Arra ballagnak el a kutyák behúzott farokkal.

És a frakkos zenészek meg az udvari zenészek is.

Azok ott a bolondok, formájukat vonszolják a földön.

Arra folyik a Duna is, viszi és vigasztalja a vizét.

Mind, el, ugyanarra.

- Nézd apu! Ott mennek a lányok, és mind milyen gyönyörü!

- Látom... mivel kented össze a trikódat?

Ott megy el Fényes Ösztön emléktől emlékig lopózva.

Ott megy May Károly egy bárányhimlőt terelve arra.

Ott tanárt tanárok kísérnek fegyelmezetten, hórihorgasan.

Ott megy el a lekésett biciklitúra is.

Ott gördül a golyó a toll végén messzi füzetekben.

Ott megy el a lisszaboni autó, körülötte cigarettafelhő,

és ott száll ki Móni, aki később nem akart élni.

Mind, el, ugyanarra.

- Nézd anyu! Ott mennek a férfiak, milyen helyesek mind!

- Igen... de mi lett a trikóddal kicsi foltom?

Ott repülnek a vadlibák meg a hangjuk.

Az a hátsó fekete a kényszer, ami hozta-viszi őket.

Arra szárad fel a felszín, ürül ki alul a csatorna.

Az ott a tavasz, a nyár, az ősz, a tél külön nejlonzsákokba téve.

Ott mennek az egyszer meglátottak, meg a többször, meg a mégsem.

Ott mennek a régiek és az eljövendők.

Ott mennek a régiek és az eljövendők.

Ott mennek a locsolóautók víz helyett tiszta vízzel.

Mind, el, ugyanarra. 


\section{SZÁZAD, „B" VÁLTOZAT}

Minden út a halálba vezet.

Megdöbbentem és csak várok,

Róma körül sötétzöld övezet:

Könnyü eltéveszteni a Várost.

Minden út a halálba vezet,

Minden úton autókaravánok.

Fenyvesek, indokolt rémület:

Ez nem Róma széle, biztos.

A sztráda aljában lakott üreg,

Az autók zöme horpadt és piszkos,

Egy egész évszázad jött itt közbe,

Ez nem Róma széle, biztos.

A benzint, ha elbújt vagy elfolyt,

Itt már nem tölthetjük újra,

Itt most az működik, ami megvolt -

Végelátható szürke túra.

Örült kissrácok dobálják a konvojt

$S$ ez az évszázad kezdődik újra.

Csak most rosszabbak a feltételek,

Megdöbbentem és csak várok:

Minden út a halálba vezet,

Könnyü eltéveszteni a Várost.

Róma körül zöld méregövezet -

A két óceánig tart a Város. 